\title{
Evaluation of Drinking Water Quality Using the Water Quality Index (WQI), the Synthetic Pollution Index (SPI) and Geospatial Tools in Lianhuashan District, China
}

\author{
Tian Hui ${ }^{1,2,3 *}$, Liang Xiujuan ${ }^{2,3}$, Sun Qifa ${ }^{1}$, Liu Qiang ${ }^{1}$, Kang Zhuang ${ }^{1}$, Gong Yan ${ }^{1}$ \\ ${ }^{1}$ Shenyang Geological Survey Center, China Geological Survey, Shenyang 110034, China \\ ${ }^{2}$ Key Laboratory of Groundwater Resources and Environment, Ministry of Education, Jilin University, \\ Changchun 130021, China \\ ${ }^{3}$ College of New Energy and Environment, Jilin University, Changchun 130021, China
}

Received: 5 February 2020

Accepted: 18 April 2020

\begin{abstract}
Due to the impact of human agricultural production and climate and environmental changes, the applicability of groundwater for drinking purposes has attracted widespread attention. In order to quantify the hydrochemical characteristics of groundwater in Lianhuashan and evaluate its suitability for assessing water for drinking purposes, 71 groundwater samples were collected and analyzed. The results show that groundwater in aquifers in the study area is weakly alkaline. The abundance is in the order $\mathrm{HCO}_{3}>\mathrm{Cl}>\mathrm{SO}_{4}{ }^{2-}$ for anions, and $\mathrm{Ca}^{2+}>\mathrm{Na}^{+}>\mathrm{Mg}^{2+}$ for cations. Groundwater chemical types were dominated by $\mathrm{HCO}_{3}-\mathrm{Ca}, \mathrm{HCO}_{3}-\mathrm{Ca} \bullet \mathrm{Mg}$, and $\mathrm{HCO}_{3}-\mathrm{Ca} \bullet \mathrm{Na}$. The Factor analysis, and PCA analysis show that ion exchange, and rock weathering are the main reasons affecting the water chemical composition in Lianhuashan. The analysis of water samples based on the WQI model revealed that about $69.09 \%, 25.45 \%, 1.81 \%$, and $3.63 \%$ of the water samples were excellent, good, very poor, and unsuitable for drinking purposes, respectively. The analysis of water samples based on the SPI model showed that $18.30 \%, 66.19 \%, 7.04 \%$, and $8.45 \%$ of the water samples were suitable, slightly polluted, moderately polluted, and highly polluted, respectively. The spatial distribution maps of the water quality index and the synthetic pollution index show that most of the groundwater resources in the study area are clean and suitable for drinking, despite the risks in the north and southwest of the study area.
\end{abstract}

Keywords: WQI, groundwater quality assessment, hydrochemistry, SPI, China

*e-mail: 359585977@qq.com 


\section{Introduction}

Water is one of the natural resources necessary for human survival and economic development. [1]. However, in arid and semi-arid regions, uneven distribution of groundwater and surface water resources has become a contradiction that restricts living standards and economic development [2]. Understanding the relationship between groundwater and water demand for agricultural production is important for sustainable agricultural development [3]. Groundwater has become the main source of fresh water for household, agricultural and industrial uses due to its simple extraction and low cost [4]. In agricultural production areas, irrigation water recharges groundwater through leakage or flows directly into rivers, which has changed the hydrodynamic conditions and led to changes in groundwater hydrochemical conditions [5]. Therefore, understanding the chemical characteristics of groundwater and its influencing factors is critical to the protection and management of groundwater resources and the sustainable use of groundwater [6].

The Songnen Plain is one of the most important grain and grass production bases in China [7]. Hailen is an important part of the northeast of the Songnen Plain and plays an important role in agricultural production. After 1995, grain production increased significantly, especially rice production. At the same time, with the increase of rice yield, groundwater irrigated area increased rapidly [8]. The contradiction between the uneven distribution of water resources and the demand for irrigation water has become increasingly prominent, and farmers have to extract groundwater from aquifers for dryland irrigation. In the end, it will lead to a series of environmental and geologic problems, such as soil secondary salinization [9], the core of depression [1011], wetland degradation [12-13], and water quality deterioration [14-15]. Therefore, the hydrogeochemical characteristics of groundwater and drinking water quality in the Lianhua district urgently need to be identified. This may restrict the protection and proper use of groundwater resources, especially the drinking water safety issues of local residents.

In order to study the hydrochemical status and the quality of groundwater in Lianhuashan, and quantitatively analyze the applicability of groundwater for drinking, 71 groundwater samples were collected from Lianhuashan between June and October in 2018. Using GIS and SPSS software, the hydrochemical properties and evolution of groundwater in the study area were characterized. The special purpose of this study is to (1) explore the hydrochemical characteristics of groundwater; (2) understand the evolution of groundwater through Factor Analysis, and PCA analysis; (3) evaluate the applicability of groundwater as drinking water using WQI and SPI models and the parameters recommended in the WHO guidelines. The results of the study help local governments strengthen management and governance in places where the groundwater environment is fragile, thereby effectively using groundwater resources in the river basin.

\section{Study Area}

\section{Study Area Description}

The Lianhuashan unique area is located in the central part of Jilin Province in northeast China, adjacent to the southeast edge of the Songnen Plain. The study area is between the latitudes of $43^{\circ} 45^{\circ}-43^{\circ} 57^{\prime} \mathrm{N}$ and the longitudes of $125^{\circ} 28^{\circ}-125^{\circ} 50^{\prime} \mathrm{E}$, covering an area of $417 \mathrm{~km}^{2}$. In 2014, the permanent population was about 59,000, and the regional GDP was 150 billion yuan. The entire area includes three towns, including Quanyan Town in the west, Quannongshan Town in the middle, and Sijiazi Town in the east (Fig. 1). Located in the temperate continental semi-humid monsoon climate of the northern hemisphere, Lianhua Mountain has four distinct seasons [16].

The average precipitation over the years is between 500 and $600 \mathrm{~mm}$, mainly concentrated in June to August. The multi-year average temperature is $4.9-5.5^{\circ} \mathrm{C}$, and the average evapotranspiration is $1741 \mathrm{~mm}$. The altitude is between 190-280 meters. The terrain slopes from southeast to northwest. The landform is divided into wavy terraces in the west, low hills in the middle, and Shitokoumen reservoir in the east. Shitoukoumen Reservoir is the largest source of water for Changchun City, with a water area of $98 \mathrm{~km}^{2}$. The Wukai River, Quannong River, and Liusha River flow through the area, indicating that surface water resources are abundant [17]. The study area mainly produces rice and corn, and is the core area of agricultural production. Groundwater and surface water are mainly used for agricultural irrigation and domestic drinking. Over the past few decades, the excessive use of pesticides and fertilizers in agricultural production, as well as the overexploitation of groundwater and the discharge of domestic sewage, have led to prominent environmental and geologic problems in the region.

\section{Geology and Hydro-Geology}

Under the control of geomorphology and geological conditions, there are obvious differences between the quaternary strata and the Cretaceous strata in the study area between the eastern hilly area and the western undulating platform (Fig. 1b).

Below the wavy platform area in the west, Quaternary alluvium and Cretaceous strata are widely distributed. The Cretaceous Quantou Formation has the lithology of mudstone and siltstone interaction formations, with small thickness and poor water content. The daily output of a single well is 300-500 tons/day, which is the target layer for groundwater extraction in this area. Quaternary strata, 


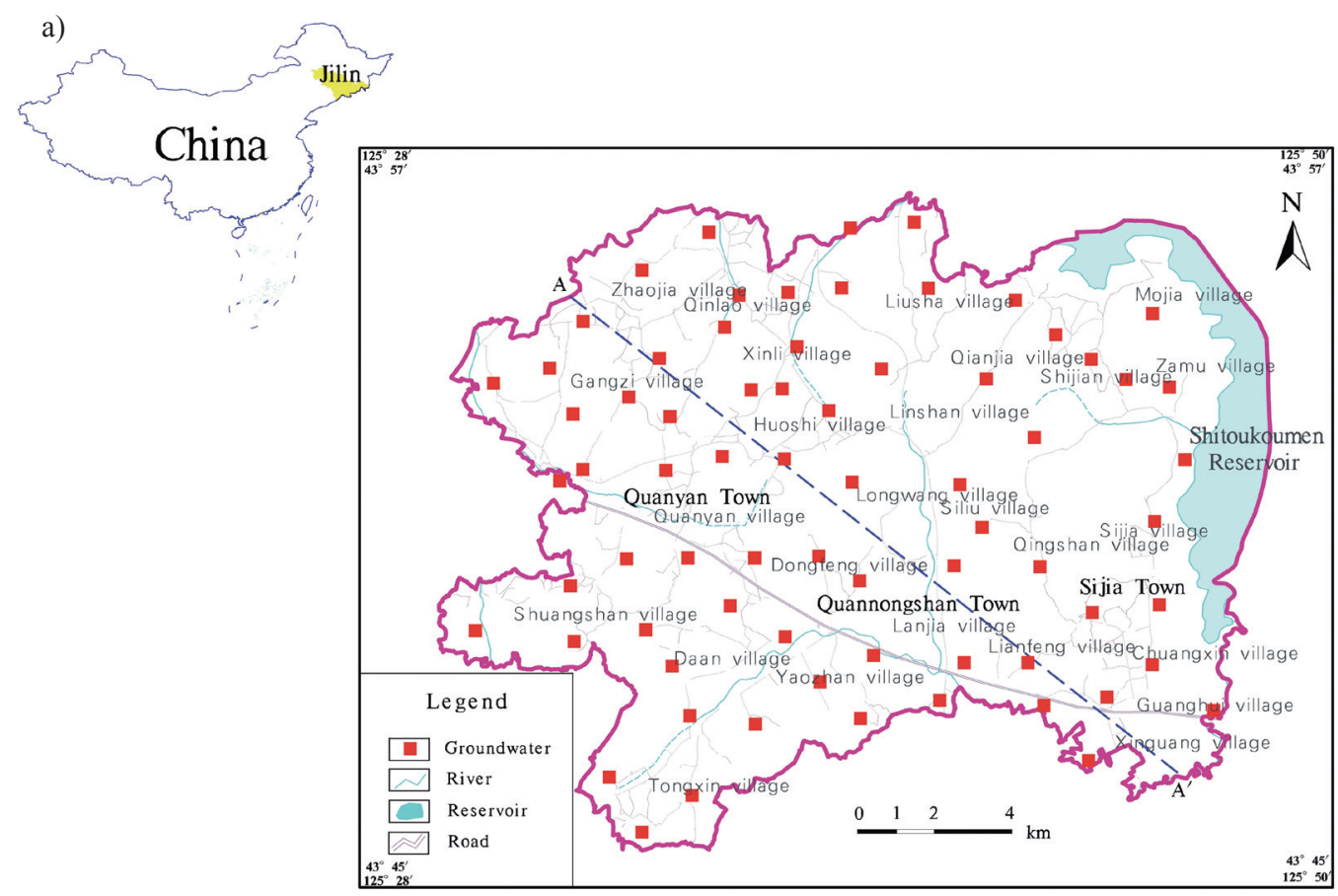

b)

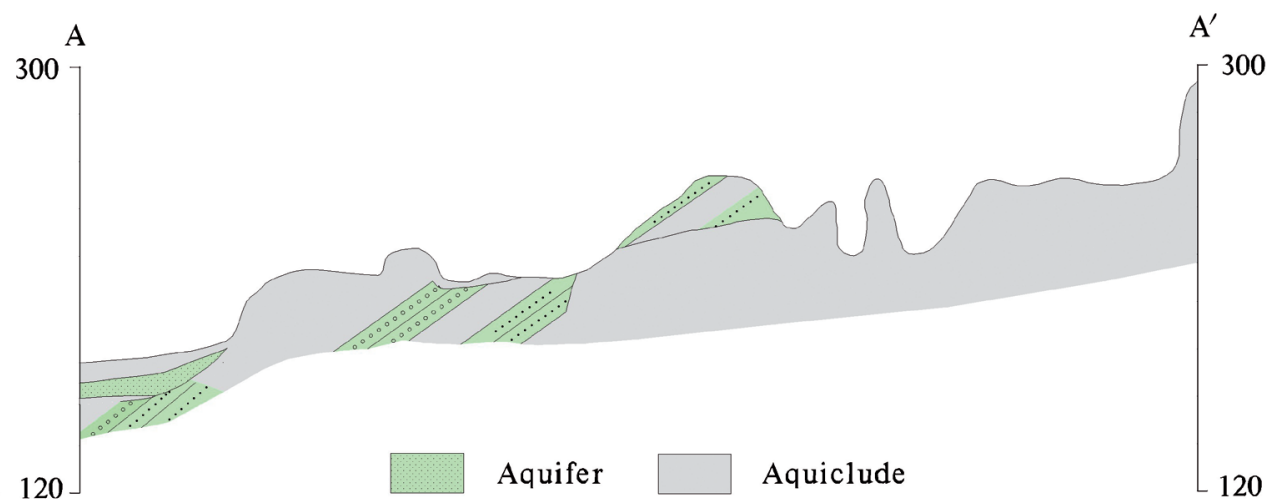

Fig. 1. a) Location of the study area with sampling points; b) Hydrogeological profile A-A`.

the upper part of which is silty clay and the lower part is a thin layer of gravel. The formation has poor water content and poor permeability of groundwater, and the daily output of a single well is less than 300 tons/day [18-19].

Below the hilly areas in the east, the aquifers are andesite, galena and granite. The thickness of the weathering shell is usually $30-40 \mathrm{~m}$. Groundwater exists in the weathering zone, but the amount of groundwater is small. The daily output of a single well is less than 300 tons/day, and the groundwater level is less than $10 \mathrm{~m}$. The spring water in the area is exposed, and most of the spring water flow is less than 0.1L/S [20].

In summary, the hydrogeological conditions in the Lianhuashan area are relatively complex, lacking thick aquifers and water storage structures, and lacking groundwater resources. Loose rock diving has the characteristics of large distribution area and easy exploitation. Although the water content of the gravel aquifer in the wave platform area is small, it can meet the needs of emergency situations.

\section{Materials and Methods}

\section{Sampling and Measurements}

According to the research plan, a total of 71 groundwater samples were collected in two batches from June to October 2018, which lasted 4 months.

Groundwater samples were taken from wells mainly used for water supply and irrigation in rural areas, and their distribution is shown in Fig. 1a). The spatial distribution of sampling points is consistent with the distribution of water intake wells in each village, which can objectively reflect the characteristics of groundwater in the study area. During the sampling process, in accordance with the Chinese hydrogeological survey standard, each pumping well was pumped for 10 minutes before sampling. The sampling process is divided into three steps. In the first step, the vial was rinsed 3 times with well water, then bottled and sealed. In the second step, the groundwater sample was stored in a $4^{\circ} \mathrm{C}$ incubator. The third step is 
to return the sample to a qualified laboratory for testing. Groundwater samples were tested in a laboratory of the Shenyang Institute of Geology and Mineral Resources within three days.

The laboratory test index includes TDS, TH, K, Na, $\mathrm{Ca}, \mathrm{Mg}, \mathrm{Cl}, \mathrm{SO}_{4}, \mathrm{HCO}_{3}, \mathrm{Fe}, \mathrm{Mn}, \mathrm{NO}_{3}, \mathrm{NO}_{2}, \mathrm{Cr}$, and $\mathrm{Pb}$. The concentration of $\mathrm{NO}_{2}$ and $\mathrm{NH}_{4}$ was obtained using gas phase molecular absorption spectrometry (GMA3376). The concentrations of major anions $\left(\mathrm{Cl}, \mathrm{SO}_{4}\right.$, and $\mathrm{NO}_{3}$ ) were determined in the laboratory using ion chromatography (ICS-3000) and the concentration of major cations $(\mathrm{Ca}, \mathrm{Na}, \mathrm{K}$, and $\mathrm{Mg}$ ) was determined in the laboratory using plasma spectroscopy (ICP6300). TDS and $\mathrm{pH}$ were measured in the field using a calibrated multi-parameter water quality analyzer (HACH-HQ40D).

\section{Drinking Water Quality Index (WQI)}

Water quality index (WQI) was a simple and useful approach for determining the overall quality of groundwater and its suitability for drinking purposes, and it has been widely used over the world [21]. The WQI was originally invented by Brown in 1970, and then improved by Backman in 1998. The World Health Organization (WHO) report (2008) emphasized that the WQI model helps to identify the impact of individual parameters of water quality and their combination on drinking water quality. Therefore, the WQI model can be used as a reliable tool for groundwater quality assessment [22]. Specifically, the WQI model can be divided into four steps, including relative weight $\left(\mathrm{W}_{\mathrm{i}}\right)$ calculation, the quality rating $\left(\mathrm{q}_{\mathrm{i}}\right)$ calculation, the subindex of parameter $\left(\mathrm{SI}_{\mathrm{i}}\right)$, and the result of WQI.

Step1: The relative weight $\left(\mathrm{W}_{\mathrm{i}}\right)$

$$
\mathrm{W}_{\mathrm{i}}=\sum \frac{W_{i}}{\sum_{i=1}^{n} W_{i}}
$$

...where $\mathrm{W}_{\mathrm{i}}$ is the relative weight of each parameter, $\mathrm{n}$ refers to the number of parameters. The weight (Wi) and relative weight (Wi) of each chemical parameter are shown in Table 1. As shown in Table 1, the weight (Wi) and relative weight (Wi) of each parameter are according to WHO standards [23].

Step2: The quality rating scale is the concentration of ions in the groundwater sample divided by the respective standard (WHO 2008 version) and multiplied by 100 .

$$
\mathrm{q}_{\mathrm{i}}=\left(\frac{C_{i}}{S_{i}}\right) \times 100
$$

...where $\mathrm{C}_{\mathrm{i}}$ is the concentration $(\mathrm{mg} / \mathrm{L})$ of ion chemical parameters in the sample, and $\mathrm{S}_{\mathrm{i}}$ is the limit value $(\mathrm{mg} / \mathrm{L})$ of the corresponding chemical parameter in the guidelines issued by the World Health Organization [24].

\begin{tabular}{|c|c|c|c|c|c|}
\hline Parameters & Units & Weight (Wi) & $\begin{array}{c}\text { Relative } \\
\text { weight (Wi) }\end{array}$ & Limit values & References \\
\hline TDS & $\mathrm{mg} / \mathrm{L}$ & 4 & 0.063 & 500 & [43] \\
\hline $\mathrm{TH}$ & $\mathrm{mg} / \mathrm{L}$ & 4 & 0.063 & 500 & [43] \\
\hline $\mathrm{PH}$ & - & 2 & 0.032 & $6.5-8.5$ & [43] \\
\hline COD & $\mathrm{mg} / \mathrm{L}$ & 5 & 0.079 & 10 & [43] \\
\hline $\mathrm{Na}$ & $\mathrm{mg} / \mathrm{L}$ & 4 & 0.063 & 200 & [43] \\
\hline $\mathrm{Ca}$ & $\mathrm{mg} / \mathrm{L}$ & 3 & 0.048 & 300 & [43] \\
\hline $\mathrm{Mg}$ & $\mathrm{mg} / \mathrm{L}$ & 3 & 0.048 & 30 & {$[43]$} \\
\hline $\mathrm{HCO}_{3}$ & $\mathrm{mg} / \mathrm{L}$ & 1 & 0.016 & 120 & [43] \\
\hline $\mathrm{Cl}$ & $\mathrm{mg} / \mathrm{L}$ & 4 & 0.063 & 250 & {$[43]$} \\
\hline $\mathrm{SO}_{4}$ & $\mathrm{mg} / \mathrm{L}$ & 3 & 0.048 & 250 & [43] \\
\hline $\mathrm{NO}_{3}$ & $\mathrm{mg} / \mathrm{L}$ & 5 & 0.079 & 50 & [43] \\
\hline $\mathrm{NO}_{2}$ & $\mathrm{mg} / \mathrm{L}$ & 5 & 0.079 & 3 & [43] \\
\hline $\mathrm{Fe}$ & $\mathrm{mg} / \mathrm{L}$ & 5 & 0.079 & 1 & {$[44]$} \\
\hline $\mathrm{Mn}$ & $\mathrm{mg} / \mathrm{L}$ & 5 & 0.079 & 0.3 & [22] \\
\hline $\mathrm{Pb}$ & $\mathrm{mg} / \mathrm{L}$ & 5 & 0.079 & 0.01 & [43] \\
\hline $\mathrm{Cr}$ & $\mathrm{mg} / \mathrm{L}$ & 5 & 0.079 & 0.05 & [43] \\
\hline SUM & - & $\sum w i=63$ & $\sum w i=1$ & - & \\
\hline
\end{tabular}

Table 1. The weight $\left(\mathrm{w}_{\mathrm{i}}\right)$ and relative weight $\left(\mathrm{W}_{\mathrm{i}}\right)$ of each chemical parameter. 
Table 2. Water quality classification based on WQI classification standards [26].

\begin{tabular}{|c|c|}
\hline Range (WQI) & Type of groundwater \\
\hline$<50$ & Excellent water \\
\hline $50 \leq \mathrm{WQI}<100$ & Good water \\
\hline $100 \leq \mathrm{WQI}<200$ & Poor Water \\
\hline $200 \leq \mathrm{WQI}<300$ & Very poor water \\
\hline$\geq 300$ & Unsuitable for drinking/Irrigation purpose \\
\hline
\end{tabular}

Step3: The subindex of parameter $\left(\mathrm{SI}_{\mathrm{i}}\right)$

$$
\mathrm{SI}_{\mathrm{i}}=W_{i} \times q_{i}
$$

...where qi represents the rating based on concentration of its parameter, $\mathrm{Wi}$ is the relative weight, $\mathrm{SI}_{i}$ is the subindex of parameter [25].

Step4: The result of WQI for a single water sample

$$
\mathrm{WQI}=\sum_{i=1}^{n} S I_{i}
$$

...where $\mathrm{n}$ is the number of parameters. According to WQI classification standards, water quality can be divided into five categories, as shown in Table 2 .

\section{The Synthetic Pollution Index (SPI)}

The SPI model can be divided into three steps, including the constant of proportionality $\left(\mathrm{K}_{\mathrm{i}}\right)$, the weight coefficient $\left(\mathrm{W}_{\mathrm{i}}\right)$, and the synthetic pollution index (SPI). The derivation and calculation of SPI involves the following three steps [27]:

Step1: The proportionality $\left(\mathrm{K}_{\mathrm{i}}\right)$

$$
\mathrm{K}_{\mathrm{i}}=\frac{1}{\sum_{i=1}^{n} \frac{1}{S_{i}}}
$$

Step2: The weight coefficient $\left(\mathrm{W}_{\mathrm{i}}\right)$

$$
\mathrm{W}_{\mathrm{i}}=\frac{K_{i}}{S_{i}}
$$

Table 3. Water quality classification based on SPI classification standards [28].

\begin{tabular}{|c|c|}
\hline Range $(\mathrm{SPI})$ & Type of groundwater \\
\hline $\mathrm{SPI}<0.2$ & Suitable \\
\hline $0.2 \leq \mathrm{SPI}<0.5$ & Slightly polluted \\
\hline $0.5 \leq \mathrm{SPI}<1.0$ & Moderately polluted \\
\hline $1.0 \leq \mathrm{SPI}<3.0$ & Highly polluted \\
\hline $\mathrm{SPI} \geq 3.0$ & Unsuitable for drinking purposes \\
\hline
\end{tabular}

Step3: The synthetic pollution index (SPI)

$$
\mathrm{SPI}=\sum_{i=1}^{n} \frac{C i}{S i} \times W i
$$

In equations (5), (6), and (7), $\mathrm{n}$ is the number of water quality parameters for analysis, and $\mathrm{Si}$ is the threshold value of each parameter according to the WHO guidelines. According to SPI classification standards, water quality can be divided into five categories, as shown in Table 3.

\section{Software}

This article uses SPSS statistical analysis software and GIS software. SPSS19.0 is used for analysis and statistics of the component of anions and cations in water, and for principal component analysis. MapGIS6.7 software is the basic software platform for geographic information systems independently developed by China. MAPGIS6.7 is used to draw the location map of the study area, the distribution map of sampling points, the water chemistry type map, WQI and SPI evaluation map.

\section{Results and Discussion}

Groundwater hydrochemistry may be affected by one or more factors. For example, regional geological conditions, the chemical composition of precipitation, hydrogeological conditions and water-rock interaction (oxidation, reduction) will change the chemical properties of groundwater. Similarly, pesticide use, fertilizer use, groundwater extraction, groundwater recharge, biological and microbial effects will also affect the composition of groundwater.

\section{Physicochemical Characteristics}

The results of statistical analysis of physical and chemical indicators of all groundwater samples are shown in Table 4.

The $\mathrm{pH}$ value of the groundwater in the study area is between 7.21 and 8.23, with an average value of 7.66. According to $\mathrm{WHO}$ guidelines, the safe range of $\mathrm{pH}$ value for drinking water is $6.5-8.5$. The $\mathrm{pH}$ value indicates that the entire water environment in the area is weakly alkaline, and the $\mathrm{pH}$ value is within the allowable range in the entire area.

Total hardness $(\mathrm{TH})$ is the result of dissolution of calcium and magnesium ions in water. The total hardness of groundwater is mainly caused by the excessive concentrations of $\mathrm{Ca}$ and $\mathrm{Mg}$. The value of the $\mathrm{TH}$ for the groundwater in the study area is 39.80-421.00 mg/L. According to WHO guidelines, the allowed hardness in water is less than $500 \mathrm{mg} / \mathrm{L}$.

The concentration of TDS in water is one of the main parameters for assessing groundwater quality. 
Table 4. Statistics of the measured parameters for water samples.

\begin{tabular}{|c|c|c|c|c|c|c|}
\hline Parameters & Unit & Minimum & Maximum & Mean & SD & CV (\%) \\
\hline $\mathrm{TDS}$ & $\mathrm{mg} / \mathrm{L}$ & 40.82 & 1169.62 & 276.49 & 218.03 & 78.86 \\
\hline $\mathrm{TH}$ & $\mathrm{mg} / \mathrm{L}$ & 60.76 & 748.16 & 229.06 & 128.48 & 56.09 \\
\hline $\mathrm{pH}$ & - & 6.25 & 7.19 & 6.71 & 0.25 & 3.73 \\
\hline $\mathrm{COD}$ & $\mathrm{mg} / \mathrm{L}$ & 0.30 & 9.60 & 1.49 & 1.47 & 98.81 \\
\hline $\mathrm{Ca}$ & $\mathrm{mg} / \mathrm{L}$ & 15.68 & 202.41 & 62.57 & 36.39 & 58.16 \\
\hline $\mathrm{Mg}$ & $\mathrm{mg} / \mathrm{L}$ & 4.28 & 58.69 & 16.68 & 36.39 & 218.23 \\
\hline $\mathrm{Na}$ & $\mathrm{mg} / \mathrm{L}$ & 7.87 & 63.69 & 20.92 & 11.33 & 54.16 \\
\hline $\mathrm{Cl}$ & $\mathrm{mg} / \mathrm{L}$ & 3.45 & 202.50 & 44.18 & 39.67 & 89.80 \\
\hline $\mathrm{SO}{ }_{4}$ & $\mathrm{mg} / \mathrm{L}$ & 2.39 & 155.84 & 36.61 & 29.08 & 79.43 \\
\hline $\mathrm{HCO}$ & $\mathrm{mg} / \mathrm{L}$ & 45.76 & 319.62 & 136.07 & 66.43 & 48.82 \\
\hline $\mathrm{NO}_{3}$ & $\mathrm{mg} / \mathrm{L}$ & 0.02000 & 340.49 & 70.38 & 82.40 & 117.09 \\
\hline $\mathrm{NO}_{2}$ & $\mathrm{mg} / \mathrm{L}$ & 0.00472 & 0.35 & 0.03 & 0.0520 & 183.46 \\
\hline $\mathrm{Fe}$ & $\mathrm{mg} / \mathrm{L}$ & 0.02050 & 21.98 & 1.43 & 3.58 & 251.21 \\
\hline $\mathrm{Mn}^{\mathrm{Cr}}$ & $\mathrm{mg} / \mathrm{L}$ & 0.00110 & 3.08100 & 0.25158 & 0.60000 & 238.49 \\
\hline $\mathrm{Pb}$ & $\mathrm{mg} / \mathrm{L}$ & 0.00100 & 0.03000 & 0.00714 & 0.00660 & 92.50 \\
\hline $\mathrm{Co}^{2}$ & 0.00100 & 0.21040 & 0.00816 & 0.02500 & 306.30 \\
\hline
\end{tabular}

$\mathrm{CV}=$ Coefficient of variation, $\mathrm{SD}=$ Standard deviation

According to WHO guidelines, the TDS allowable value for drinking water is $500 \mathrm{mg} / \mathrm{L}$. In the study area, the TDS value of groundwater was $82.10-681.00 \mathrm{mg} / \mathrm{L}$ with an average value of $193.87 \mathrm{mg} / \mathrm{L}$. The concentration of TDS in groundwater is relatively low and suitable for consumption.

The COD in the water represents the degree of pollution of the water environment. The value of the COD for the groundwater in the study area is $0.43-13.10 \mathrm{mg} / \mathrm{L}$.

Cations and anions show significant difference in groundwater. As shown in Table 1, the concentrations of $\mathrm{Ca}^{2+}, \mathrm{Mg}^{2+}$, and $\mathrm{Na}^{+}$in groundwater are observed in the ranges of $15.68-202.41 \mathrm{mg} / \mathrm{L}, 4.28-58.69 \mathrm{mg} / \mathrm{L}$, 7.78-63.69 $\mathrm{mg} / \mathrm{L}$, respectively. The average concentrations of the analyzed cations are in the order of $\mathrm{Ca}^{2+}>\mathrm{Na}^{+}>\mathrm{Mg}^{2+}$. The concentrations of $\mathrm{SO}_{4}^{2-}, \mathrm{HCO}_{3}^{-}$, and $\mathrm{Cl}^{-}$in groundwater are observed in the ranges of 3.39-155.84 mg/L, 45.76-319.62 mg/L, 3.45-202.50 mg/L, respectively. The average concentrations of the analyzed anions are in the order of $\mathrm{HCO}_{3}>\mathrm{Cl}^{-}>\mathrm{SO}_{4}{ }^{2-}$.

In recent years, the concentrations of $\mathrm{Fe}$ and $\mathrm{Mn}$ in groundwater have received much attention and have been included in the evaluation standards for drinking water. In this study, the concentration of $\mathrm{Fe}$ in groundwater ranges from $0.0205 \mathrm{mg} / \mathrm{L}$ to $21.98 \mathrm{mg} / \mathrm{L}$ with the mean value of $1.43 \mathrm{mg} / \mathrm{L}$ (Fig. 2c). The concentration of $\mathrm{Mn}$ in groundwater ranges from $0.0010 \mathrm{mg} / \mathrm{L}$ to $3.0810 \mathrm{mg} / \mathrm{L}$ with the mean value of $0.2515 \mathrm{mg} / \mathrm{L}$ (Fig. 2d). According to WHO guidelines, the allowable concentration for $\mathrm{Fe}$ in water is $1 \mathrm{mg} / \mathrm{L}$, and the allowable concentration for $\mathrm{Mn}$ is $0.3 \mathrm{mg} / \mathrm{L}$. The concentrations of $\mathrm{Fe}$ and $\mathrm{Mn}$ in groundwater are generally high, indicating a high concentrations of $\mathrm{Fe}$ and $\mathrm{Mn}$ in depositional environment in the aquifer throughout the study area [29].

According to studies, nitrate nitrogen in water has a greater harmful effect on humans and aquatic organisms. For example, when water with a nitrate content of greater than $10 \mathrm{mg} / \mathrm{L}$ is consumed over time, methemoglobinemia occurs. A blood methemoglobin content of $70 \mathrm{mg} / \mathrm{L}$ results in suffocation. In this study, the concentration of $\mathrm{NO}_{3}$ in groundwater ranges from $0.02 \mathrm{mg} / \mathrm{L}$ to $340.49 \mathrm{mg} / \mathrm{L}$ with the mean value of $70.38 \mathrm{mg} / \mathrm{L}$ (Figure 2a). The concentration of $\mathrm{NO}_{2}$ in groundwater ranges from $0.0047 \mathrm{mg} / \mathrm{L}$ to $0.35 \mathrm{mg} / \mathrm{L}$ with the mean value of $0.03 \mathrm{mg} / \mathrm{L}$ (Fig. 2b). According to WHO guidelines, the allowable concentration for $\mathrm{NO}_{3}$ in water is $50 \mathrm{mg} / \mathrm{L}$, and the limited concentration for $\mathrm{NO}_{2}$ is $3 \mathrm{mg} / \mathrm{L}$. The increase of nitrate concentration is closely related to the use of chemical fertilizers and the infiltration of surface nitrogen [30].

High levels of heavy metals in drinking water can cause poisoning, carcinogenesis and various diseases [31]. In this study, the concentration of $\mathrm{Cr}$ in groundwater ranges from $0.001 \mathrm{mg} / \mathrm{L}$ to $0.03 \mathrm{mg} / \mathrm{L}$ with the mean value of $0.007 \mathrm{mg} / \mathrm{L}$ (Fig. 2e). The concentration of $\mathrm{Pb}$ in groundwater ranges from $0.001 \mathrm{mg} / \mathrm{L}$ to $0.210 \mathrm{mg} / \mathrm{L}$ with the mean value of 
$0.008 \mathrm{mg} / \mathrm{L}$ (Fig. 2f). According to WHO guidelines, the allowable concentration for $\mathrm{Cr}$ in water is $0.01 \mathrm{mg} / \mathrm{L}$, and the limited concentration for $\mathrm{Pb}$ is $0.05 \mathrm{mg} / \mathrm{L}$. In summary, the concentration of $\mathrm{Cr}$ and $\mathrm{Pb}$ is within the limited range, which indicates that the content of heavy metals in groundwater is low.

a)

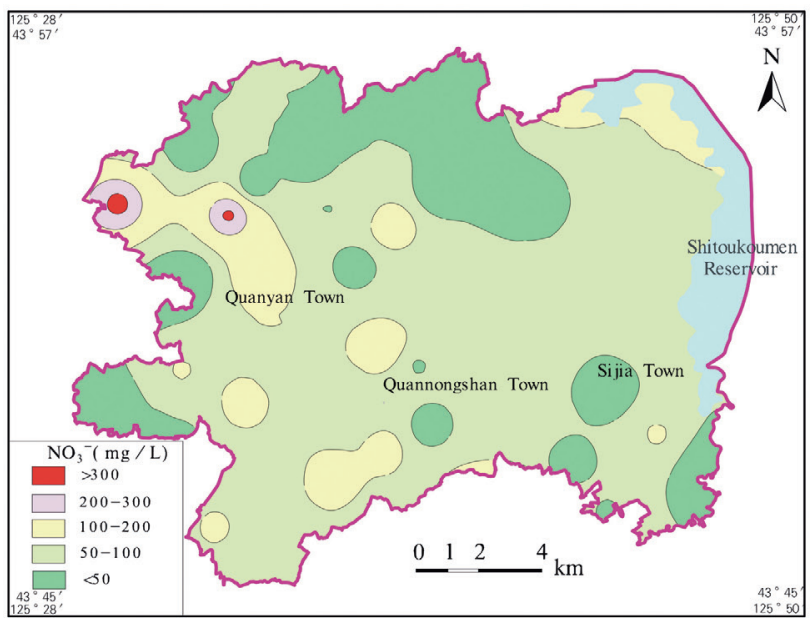

c)

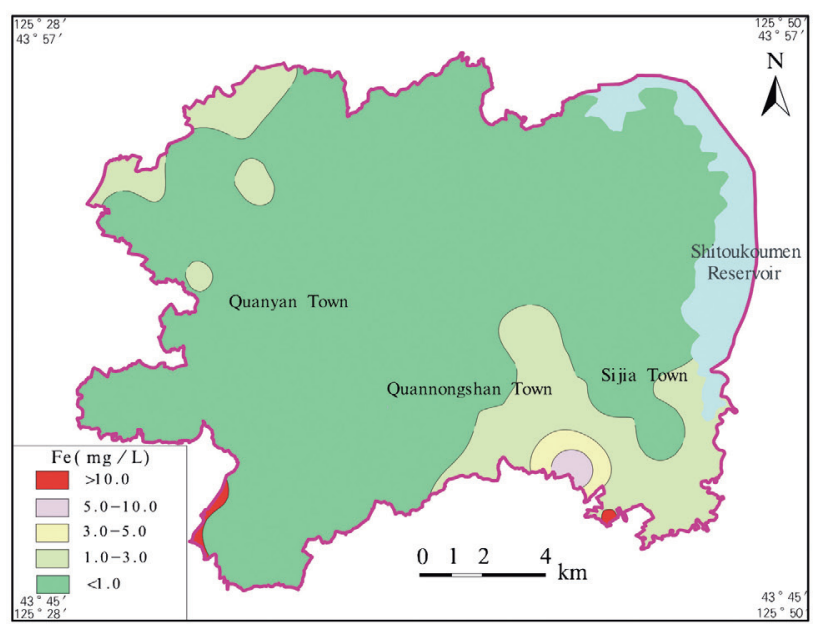

e)

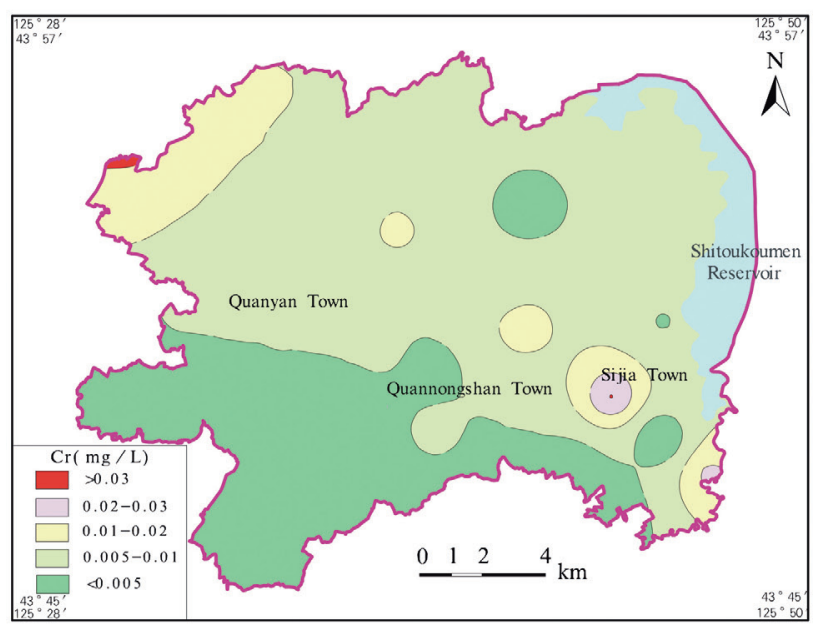

\section{The Durov Diagram and Groundwater Hydrochemical Types}

In order to accurately reflect and describe the groundwater chemistry in the study area, a Durov diagram was drawn using MapGIS 6.7 software [32].

b)

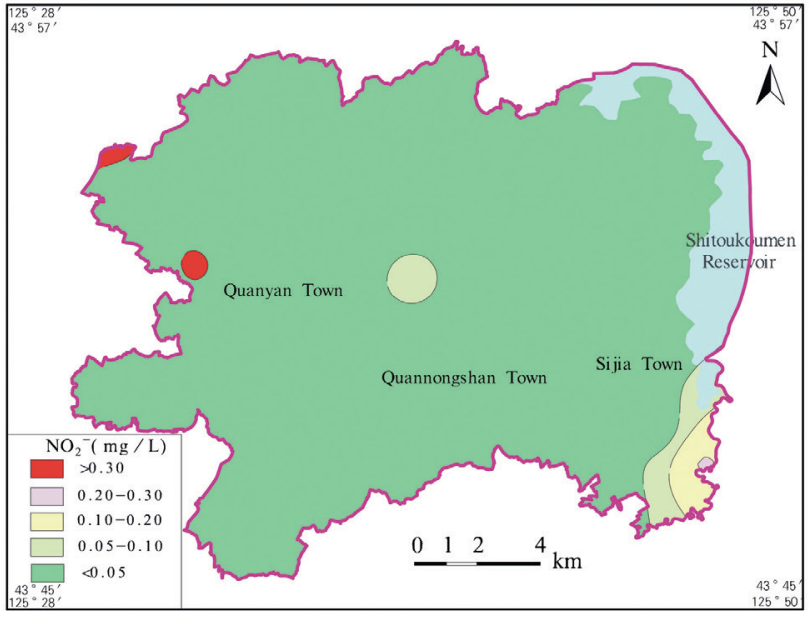

d)

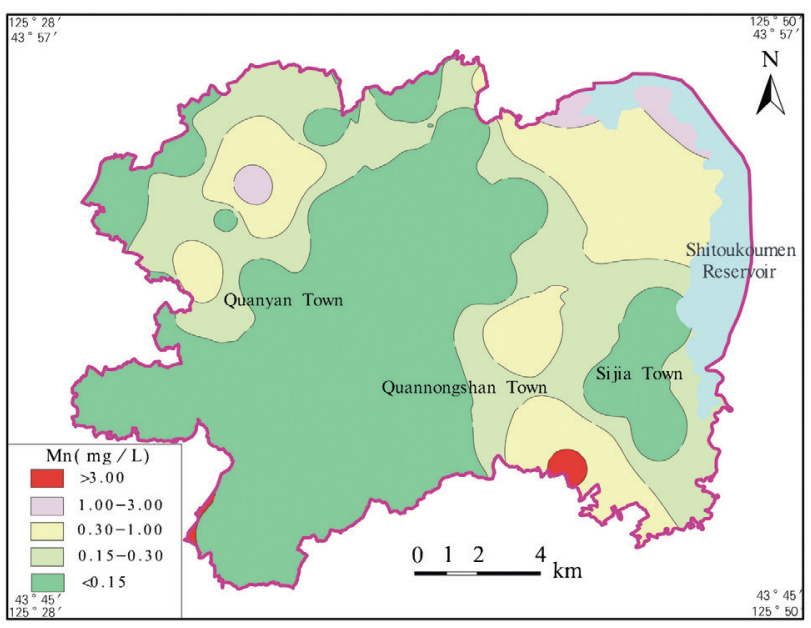

f)

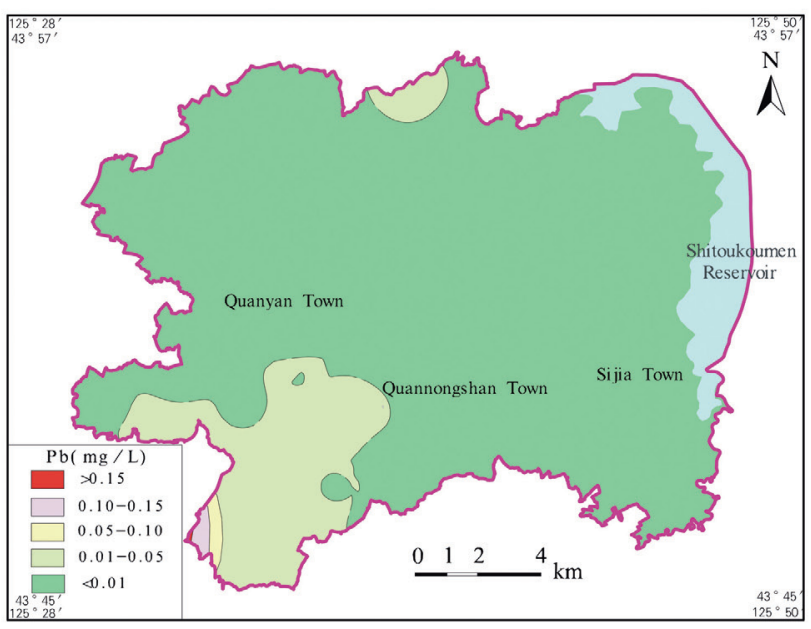

Fig. 2. Spatial distributions of groundwater chemical indexes $\left(\mathrm{NO}_{3}^{-}, \mathrm{NO}_{2}^{-}, \mathrm{Fe}, \mathrm{Mn}, \mathrm{Cr}\right.$, and $\left.\mathrm{Pb}\right)$. 


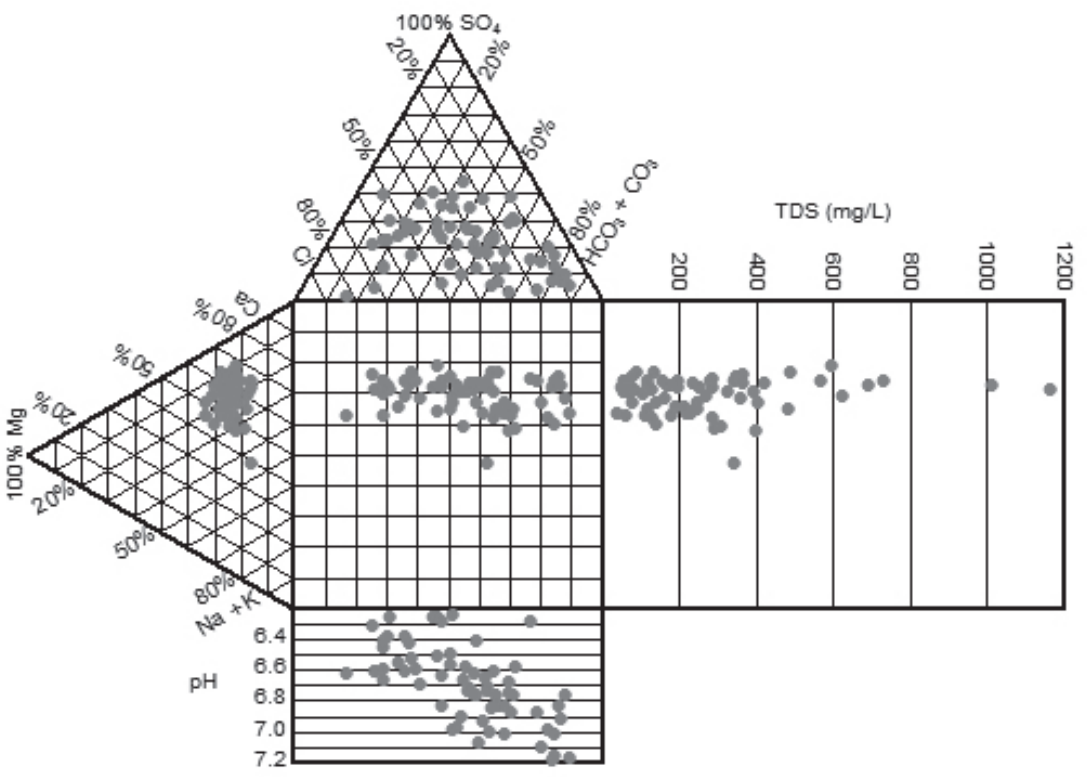

Fig. 3. Durov diagram of groundwater samples.

As shown in Fig. 3, chemical differences between groundwater anions and cations are also reflected. The diagram shows that $\mathrm{HCO}_{3}$ and $\mathrm{Cl}$ are the main anions in groundwater, while $\mathrm{Ca}$ and $\mathrm{Na}$ are the main cations. The groundwater samples had a larger variated range of TDS content varying from $40 \mathrm{mg} / \mathrm{L}$ to $1169 \mathrm{mg} / \mathrm{L}$, dominated by $\mathrm{HCO}_{3}$. These 71 samples are mainly controlled by $\mathrm{HCO}_{3}-\mathrm{Ca}, \mathrm{HCO}_{3}-\mathrm{Ca} \cdot \mathrm{Mg}, \mathrm{HCO}_{3}-\mathrm{Ca} \cdot \mathrm{Na}$ and other water chemistry types.
Factor and Principal Component Analyses

Statistical analysis and factor analysis can help identify relationships and sources of ions in groundwater. Three principal components with characteristic root values greater than 1 were extracted and analyzed (Fig. 4, Table 5).

Factor 1, with a variance of about $43.42 \%$, includes TDS, $\mathrm{Ca}^{2+}, \mathrm{Mg}^{2+}, \mathrm{TH}, \mathrm{Na}^{+}$, and $\mathrm{Cl}^{-}$, suggesting that TDS

Table 5. Groundwater physical and chemical parameter correlation matrix.

\begin{tabular}{|c|c|c|c|c|c|c|c|c|c|c|c|c|c|c|c|c|}
\hline Parameter & $\mathrm{TDS}$ & $\mathrm{TH}$ & $\mathrm{PH}$ & $\mathrm{COD}$ & $\mathrm{Ca}$ & $\mathrm{Mg}$ & $\mathrm{Na}$ & $\mathrm{Cl}$ & $\mathrm{SO}_{4}$ & $\mathrm{HCO}_{3}$ & $\mathrm{NO}_{3}$ & $\mathrm{NO}_{2}$ & $\mathrm{Fe}$ & $\mathrm{Mn}$ & $\mathrm{Cr}$ & $\mathrm{Pb}$ \\
\hline $\mathrm{TDS}$ & 1.00 & & & & & & & & & & & & & & \\
\hline $\mathrm{TH}$ & 0.83 & 1.00 & & & & & & & & & & & & & \\
\hline $\mathrm{PH}$ & -0.59 & -0.47 & 1.00 & & & & & & & & & & & & & \\
\hline $\mathrm{COD}$ & 0.33 & 0.17 & -0.05 & 1.00 & & & & & & & & & & & & \\
\hline $\mathrm{Ca}$ & 0.84 & 0.99 & -0.49 & 0.16 & 1.00 & & & & & & & & & & & \\
\hline $\mathrm{Mg}$ & 0.77 & 0.96 & -0.40 & 0.18 & 0.93 & 1.00 & & & & & & & & & & \\
\hline $\mathrm{Na}$ & 0.75 & 0.75 & -0.44 & 0.40 & 0.72 & 0.73 & 1.00 & & & & & & & & & \\
\hline $\mathrm{Cl}$ & 0.79 & 0.93 & -0.55 & 0.15 & 0.93 & 0.87 & 0.74 & 1.00 & & & & & & & & \\
\hline $\mathrm{SO}$ & 0.71 & 0.70 & -0.41 & 0.17 & 0.69 & 0.71 & 0.73 & 0.69 & 1.00 & & & & & & & \\
\hline $\mathrm{HCO}$ & 0.28 & 0.34 & 0.06 & 0.54 & 0.32 & 0.38 & 0.39 & 0.14 & 0.26 & 1.00 & & & & & & \\
\hline $\mathrm{NO}_{3}$ & 0.66 & 0.80 & -0.46 & -0.11 & 0.80 & 0.75 & 0.53 & 0.76 & 0.40 & -0.19 & 1.00 & & & & & \\
\hline $\mathrm{NO}_{2}$ & 0.10 & -0.05 & 0.06 & 0.50 & -0.06 & -0.09 & 0.33 & 0.01 & 0.04 & 0.19 & -0.14 & 1.00 & & & & \\
\hline $\mathrm{Fe}$ & -0.08 & -0.14 & 0.04 & 0.04 & -0.19 & -0.23 & 0.03 & -0.12 & -0.14 & -0.02 & -0.14 & 0.30 & 1.00 & & & \\
\hline $\mathrm{Mn}^{2}$ & 0.21 & 0.14 & -0.11 & 0.01 & 0.12 & 0.08 & 0.08 & 0.11 & 0.03 & -0.09 & 0.22 & 0.01 & 0.31 & 1.00 & & \\
\hline $\mathrm{Cr}^{\mathrm{Pb}}$ & 0.37 & 0.06 & -0.29 & 0.37 & 0.08 & -0.01 & 0.25 & 0.10 & 0.03 & 0.09 & 0.05 & 0.50 & 0.08 & 0.09 & 1.00 & \\
\hline & -0.12 & -0.03 & 0.08 & -0.07 & -0.04 & -0.06 & -0.14 & -0.10 & -0.07 & 0.12 & -0.10 & -0.06 & 0.21 & 0.13 & -0.18 & 1.00 \\
\hline
\end{tabular}




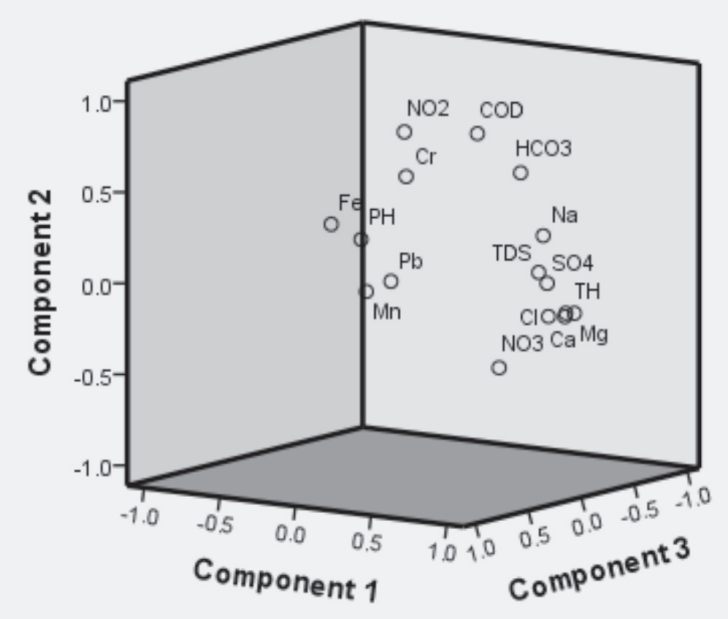

Fig. 4. PCA plot of the water (3D diagrams of factors).

and $\mathrm{TH}$ content of groundwater are mainly affected by $\mathrm{Ca}^{2+}$ and $\mathrm{Mg}^{2+}$ in the study area [33-34]. The high correlation between $\mathrm{Ca}^{2+}, \mathrm{Mg}^{2+}$ and $\mathrm{Na}^{+}$indicates that a strong exchange adsorption occurs between $\mathrm{Ca}^{2+}$, $\mathrm{Mg}^{2+}$ and $\mathrm{Na}^{+}$in groundwater. Factor 2 controls $19.62 \%$ of the water chemistry parameters, including COD, and $\mathrm{NO}_{2}^{-}$. The high correlation between COD, and $\mathrm{NO}_{2}{ }^{-}$indicates that their sources are consistent and are closely related to the use of fertilizers. Factors 2 suggest that groundwater in some areas has been contaminated with agricultural chemical fertilizers, indicating that groundwater recharged by agricultural irrigation water is the main cause of groundwater pollution [35-36]. Factor 3 contains $14.66 \%$ of all variables, including Fe and $\mathrm{Mn}$, suggesting the amount of $\mathrm{Fe}$ in groundwater is highly correlated with the content of Mn [37-38]. The high levels of $\mathrm{Fe}$ and $\mathrm{Mn}$ are related to the areas of groundwater and surface water flow pathways. However, the high $\mathrm{Fe}$ contents are related to the interaction of groundwater with silty mudstone and shale in the watershed. The high Mn concentration may be related to the high $\mathrm{Mn}$ content in the surrounding carbonates and silicates, as the water flowing through the area may be absorbing the element.

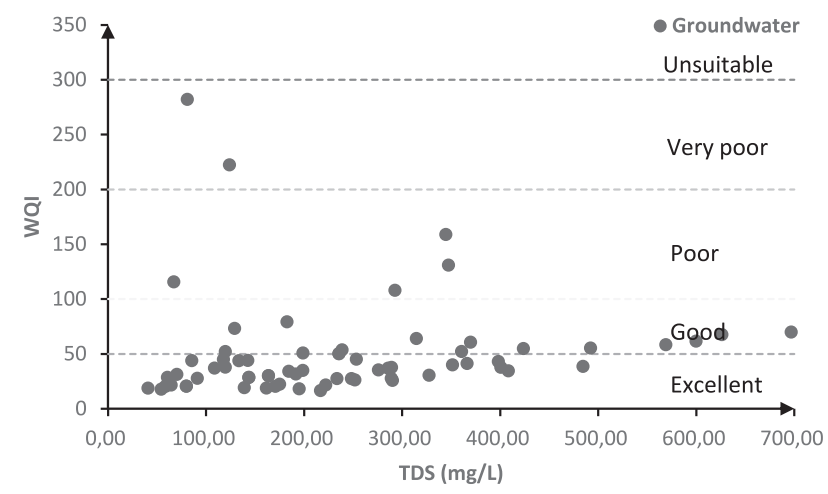

Fig. 5. The diagram of Groundwater TDS versus WQI.

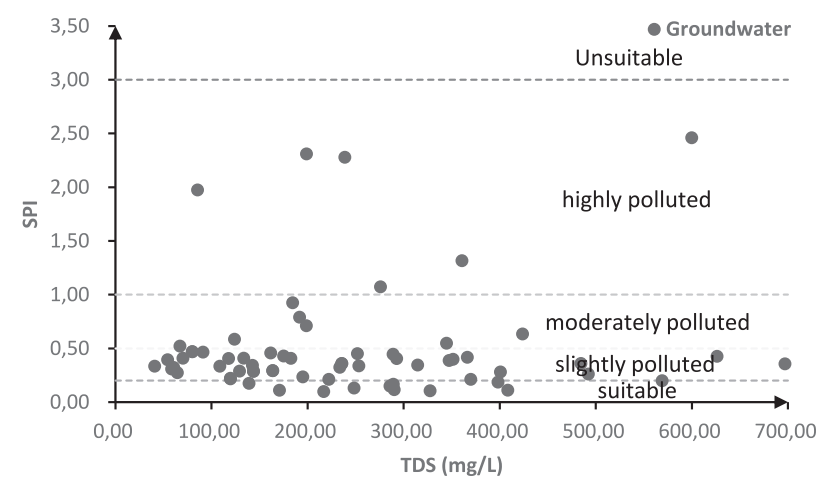

Fig. 6. The diagram of Groundwater TDS versus SPI.

\section{Water Quality for Drinking Purpose}

The results of groundwater WQI in Lianhuashan area are shown in Fig. 5 (Table 6). As shown in Fig. 5,

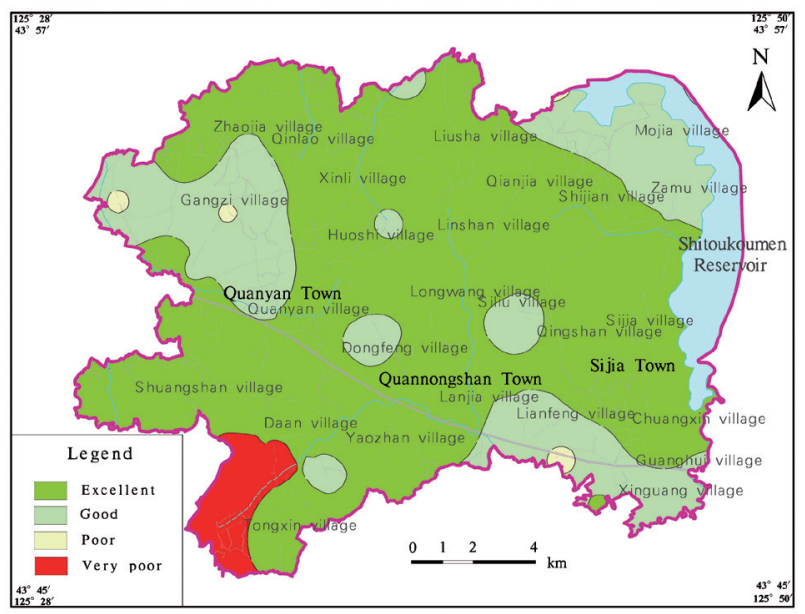

Fig. 7. Spatial distribution groundwater quality maps based on the outcomes of the WQI model.

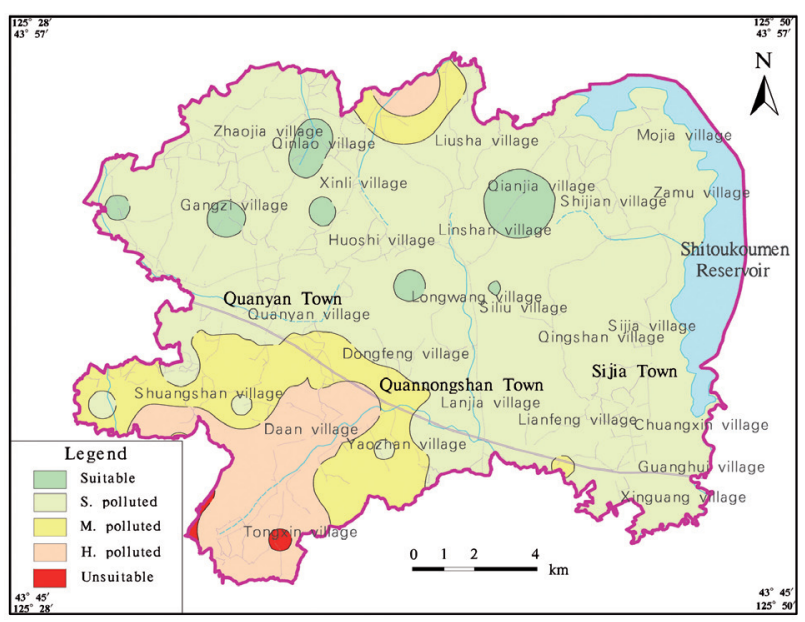

Fig. 8. Spatial distribution groundwater quality maps based on the outcomes of the SPI model. 
among the 71 groundwater samples, 45 were "excellent" (grade 1), 20 were "good" (grade 2), 4 was "poor" (grade 3 ), and 2 were "very poor" (grade 4), accounting for $63.38 \%, 28.16 \%, 5.63 \%$, and $3.63 \%$, respectively. The calculation results of WQI show that the groundwater in the study area is excellent for drinking purpose, while the groundwater in some places is not suitable for drinking [39-41].

The results of groundwater SPI in Lianhuashan area are shown in Fig. 6 (Table 7). As shown in Fig. 6 (Table 7), among the 71 groundwater samples, 13 were "suitable" (grade 1), 47 were "slightly polluted" (grade 2), 5 was "moderately polluted" (grade 3), and 6 were "highly polluted" (grade 4), accounting for $18.30 \%$, $66.19 \%, 7.04 \%$, and $8.45 \%$, respectively. The calculation results of SPI show that the groundwater in the study area is suitable, while the groundwater in some places is slightly polluted.

Based on the evaluation results of the water quality index model, the drinking water quality evaluation map of the study area was drawn (Fig. 7). The spatial distribution of the water quality index shows that most of the groundwater index concentration ranges in the study area are below the WHO guidelines and are therefore suitable for drinking. It is worth noting that in the southwest of the study area, the WQI index of groundwater in small areas was found to be higher than 200. The WQI index exceeded the standard, mainly due to the extremely high concentration of Fe and $\mathrm{Mn}$ in groundwater. The high concentrations of $\mathrm{Fe}$ and $\mathrm{Mn}$ are not only affected by high concentrations in the Cretaceous aquifer, but also affected by human agricultural production [42]. Therefore, the centralized water supply wells in this area should be added with $\mathrm{Fe}$ and $\mathrm{Mn}$ purification devices before drinking. Overall, it was learned from this study that the quality of groundwater complies with drinking water specifications according to WHO guidelines.

Based on the evaluation results of the synthetic pollution index model, the drinking water quality

Table 6. Categories of groundwater based on the WQI model results.

\begin{tabular}{|c|c|c|c|c|c|c|c|c|}
\hline G.W. NO. & WQI & Rank & G.W. NO. & WQI & Rank & G.W. NO. & WQI & Rank \\
\hline 1 & 27.50 & Excellent & 25 & 55.34 & Good & 49 & 37.91 & Excellent \\
\hline 2 & 60.67 & Good & 26 & 27.47 & Excellent & 50 & 28.55 & Excellent \\
\hline 3 & 61.61 & Good & 27 & 37.70 & Excellent & 51 & 28.55 & Excellent \\
\hline 4 & 21.65 & Excellent & 28 & 107.98 & Poor & 52 & 20.58 & Excellent \\
\hline 5 & 25.84 & Excellent & 29 & 45.15 & Excellent & 53 & 20.58 & Excellent \\
\hline 6 & 36.95 & Excellent & 30 & 41.26 & Excellent & 54 & 21.61 & Excellent \\
\hline 7 & 165.23 & Poor & 31 & 16.57 & Excellent & 55 & 282.07 & Very poor \\
\hline 8 & 165.23 & Poor & 32 & 158.87 & Poor & 56 & 50.82 & Good \\
\hline 9 & 18.16 & Excellent & 33 & 112.18 & Poor & 57 & 52.20 & Good \\
\hline 10 & 37.76 & Excellent & 34 & 73.25 & Good & 58 & 31.66 & Excellent \\
\hline 11 & 30.10 & Excellent & 35 & 18.85 & Excellent & 59 & 54.87 & Good \\
\hline 12 & 30.10 & Excellent & 36 & 109.96 & Poor & 60 & 34.13 & Excellent \\
\hline 13 & 64.02 & Good & 37 & 20.42 & Excellent & 61 & 34.93 & Excellent \\
\hline 14 & 43.07 & Excellent & 38 & 22.34 & Excellent & 62 & 19.21 & Excellent \\
\hline 15 & 30.52 & Excellent & 39 & 50.20 & Good & 63 & 222.36 & Very poor \\
\hline 16 & 69.89 & Good & 40 & 50.20 & Good & 64 & 53.69 & Good \\
\hline 17 & 58.37 & Good & 41 & 28.62 & Excellent & 65 & 35.38 & Excellent \\
\hline 18 & 39.98 & Excellent & 42 & 37.04 & Excellent & 66 & 43.86 & Excellent \\
\hline 19 & 34.55 & Excellent & 43 & 52.14 & Good & 67 & 27.73 & Excellent \\
\hline 20 & 26.25 & Excellent & 44 & 31.31 & Excellent & 68 & 43.78 & Excellent \\
\hline 21 & 67.59 & Good & 45 & 79.24 & Good & 69 & 17.78 & Excellent \\
\hline 22 & 27.74 & Excellent & 46 & 44.98 & Excellent & 70 & 115.66 & Poor \\
\hline 23 & 130.92 & Poor & 47 & 20.34 & Excellent & 71 & 18.77 & Excellent \\
\hline 24 & 38.60 & Excellent & 48 & 44.05 & Excellent & & & \\
\hline
\end{tabular}


Table 7 Categories of groundwater based on the SPI model results.

\begin{tabular}{|c|c|c|c|c|c|c|c|c|}
\hline GW. NO. & SPI & Rank & GW. NO. & SPI & Rank & GW. NO. & SPI & Rank \\
\hline 1 & 0.32 & SP* & 25 & 0.26 & SP* & 49 & 0.22 & $\mathrm{SP} *$ \\
\hline 2 & 0.21 & SP* & 26 & 0.13 & $\mathrm{~S}^{*}$ & 50 & 0.29 & $\mathrm{SP} *$ \\
\hline 3 & 2.46 & $\mathrm{HP}^{*}$ & 27 & 0.17 & $\mathrm{~S}^{*}$ & 51 & 0.29 & $\mathrm{SP} *$ \\
\hline 4 & 0.21 & SP* & 28 & 0.41 & $\mathrm{SP}^{*}$ & 52 & 0.47 & $\mathrm{SP} *$ \\
\hline 5 & 0.12 & $\mathrm{~S}^{*}$ & 29 & 0.34 & $\mathrm{SP}^{*}$ & 53 & 0.47 & $\mathrm{SP}^{*}$ \\
\hline 6 & 0.15 & $\mathrm{~S}^{*}$ & 30 & 0.42 & $\mathrm{SP}^{*}$ & 54 & 0.27 & $\mathrm{SP}^{*}$ \\
\hline 7 & 0.40 & SP* & 31 & 0.10 & $\mathrm{~S}^{*}$ & 55 & 7.91 & $\mathrm{U}^{*}$ \\
\hline 8 & 0.40 & SP* & 32 & 0.55 & MP* & 56 & 2.31 & $\mathrm{HP}^{*}$ \\
\hline 9 & 0.24 & SP* & 33 & 0.12 & $\mathrm{~S}^{*}$ & 57 & 1.32 & $\mathrm{HP}^{*}$ \\
\hline 10 & 0.28 & SP* & 34 & 0.29 & $\mathrm{SP}^{*}$ & 58 & 0.79 & MP* \\
\hline 11 & 0.29 & SP* & 35 & 0.46 & $\mathrm{SP}^{*}$ & 59 & 0.63 & MP* \\
\hline 12 & 0.29 & SP* & 36 & 0.18 & $\mathrm{~S}^{*}$ & 60 & 0.92 & MP* \\
\hline 13 & 0.35 & SP* & 37 & 0.11 & $\mathrm{~S}^{*}$ & 61 & 0.71 & MP* \\
\hline 14 & 0.19 & $\mathrm{~S}^{*}$ & 38 & 0.43 & $\mathrm{SP}^{*}$ & 62 & 0.17 & $\mathrm{~S}^{*}$ \\
\hline 15 & 0.11 & $\mathrm{~S}^{*}$ & 39 & 0.36 & $\mathrm{SP}^{*}$ & 63 & 0.59 & MP* \\
\hline 16 & 0.36 & SP* & 40 & 0.36 & $\mathrm{SP}^{*}$ & 64 & 2.28 & $\mathrm{HP}^{*}$ \\
\hline 17 & 0.20 & SP* & 41 & 0.32 & $\mathrm{SP}^{*}$ & 65 & 1.07 & $\mathrm{HP}^{*}$ \\
\hline 18 & 0.40 & SP* & 42 & 0.33 & $\mathrm{SP}^{*}$ & 66 & 1.97 & $\mathrm{HP}^{*}$ \\
\hline 19 & 0.11 & $\mathrm{~S}^{*}$ & 43 & 0.22 & $\mathrm{SP}^{*}$ & 67 & 0.47 & $\mathrm{SP}^{*}$ \\
\hline 20 & 0.45 & SP* & 44 & 0.41 & $\mathrm{SP}^{*}$ & 68 & 0.41 & $\mathrm{SP}^{*}$ \\
\hline 21 & 0.43 & SP* & 45 & 0.41 & $\mathrm{SP}^{*}$ & 69 & 0.39 & $\mathrm{SP} *$ \\
\hline 22 & 0.45 & SP* & 46 & 0.41 & $\mathrm{SP}^{*}$ & 70 & 0.52 & $\mathrm{MP}^{*}$ \\
\hline 23 & 0.39 & SP* & 47 & 0.31 & $\mathrm{SP}^{*}$ & 71 & 0.33 & $\mathrm{SP}^{*}$ \\
\hline 24 & 0.36 & SP* & 48 & 0.34 & SP* & & & \\
\hline
\end{tabular}

$\mathrm{S}^{*}=$ suitable, $\mathrm{SP}^{*}=$ slightly polluted, $\mathrm{MP} *=$ moderately polluted, $\mathrm{HP} *=$ highly polluted, $\mathrm{US}^{*}=$ unsuitable

evaluation map of the study area was drawn (Fig. 8). The spatial distribution of the synthetic pollution index shows that the groundwater indicators in most areas of the study area do not exceed the WHO guidelines, but there are signs of groundwater pollution in some places. Similar to the WQI spatial distribution results, in the north and southwest of the study area, the SPI index of groundwater in small areas was found to be higher than 1.00. The SPI index exceeds 1.0 , indicating that there is a high risk of contamination of groundwater in these areas, mainly due to the extremely high content of $\mathrm{Pb}$ in groundwater. The high concentration of $\mathrm{Pb}$ is mainly due to the impact of human activities [43]. In this area, there are largescale landfills, and the leakage of landfill leachate contaminates groundwater, leading to an increase in $\mathrm{Pb}$ concentration. Therefore, in order to prevent serious pollution of groundwater, the leakproof layer of the landfill should be reinforced.

\section{The Relationship between WQI and SPI Models}

The relationship between the WQI and SPI models is established, and the water categories indicated by the two models are correlated through regression analysis, Eq. (8). The relationship indicates a good correlation between WQI and SPI models $\left(\mathrm{R}^{2}=0.71\right)$.

$$
\mathrm{SPI}=0.0233 \times \mathrm{WQI}-0.5647
$$

\section{Conclusions}

In this study, the factors affecting Lianhuashan's groundwater chemistry and its quality are discussed in detail, and the groundwater hydrogeological process is analyzed. Groundwater quality assessments were also introduced to assess suitability for drinking. The following three conclusions are concluded: 
1. Groundwater in aquifers in the study area is weakly alkaline. The abundance is in the order $\mathrm{HCO}_{3}>\mathrm{Cl}^{-}>\mathrm{SO}_{4}^{2-}$ for anions, and $\mathrm{Ca}^{2+}>\mathrm{Na}^{+}>\mathrm{Mg}^{2+}$ for cations, resulting in that the water types were dominated by $\mathrm{HCO}_{3}-\mathrm{Ca}, \mathrm{HCO}_{3}-\mathrm{Ca} \bullet \mathrm{Mg}$, and $\mathrm{HCO}_{3}-\mathrm{Ca} \cdot \mathrm{Na}$.

2. The Factor analysis, and PCA analysis show that ion exchange, rock weathering are the main reasons affecting the water chemical composition in Lianhuashan. At the same time, the high scores of $\mathrm{NO}_{3}^{-}, \mathrm{NO}_{2}^{-}, \mathrm{Fe}$, and $\mathrm{Mn}$ must be widely concerned and may become the main environmental geological problems in the area.

3. The analysis of water samples based on the WQI model revealed that about $69.09 \%, 25.45 \%, 1.81 \%$, and $3.63 \%$ of the water samples were excellent, good, very poor, and unsuitable for drinking purposes, respectively. The analysis of water samples based on the SPI model showed that $18.30 \%, 66.19 \%, 7.04 \%$, and $8.45 \%$ of the water samples were suitable, slightly polluted, moderately polluted, and highly polluted, respectively. The spatial distribution maps of the water quality index and the synthetic pollution index show that most of the groundwater resources in the study area are clean and suitable for drinking, despite the risks in the north and southwest of the study area.

\section{Acknowledgement}

This work was supported by the projects of hydrological and geological survey in Hailun, Bayan and Wuhe Area (Item Number: DD20190340-1). We give thanks to Yonggen Zhang, Shanghai Du, Zhuang Kang and Xiaoqing Sun for helping us with mapping and writing skills in the process of writing this paper. We are also grateful to valuable comments and suggestions given by the editors and the anonymous reviewers.

\section{Conflict of Interest}

The authors declare no conflict of interest.

\section{References}

1. GU B., GE Y., CHANG S.X., LUO W., CHANG J. Nitrate in groundwater of China: sources and driving forces. Glob. Environ. Change. 23, 1112, 2013.

2. BRHANE G.K. Characterization of hydro chemistry and groundwater quality evaluation for drinking purpose in Adigrat area, Tigray, northern Ethiopia. Water Science. 32 (2), 213, 2018.

3. HUSSAIN S.A., HUSSAIN A., FATIMA U., ALI W., HUSSAIN A., HUSSAIN N. Evaluation of drinking water quality in urban areas of Pakistan, a case study of Gulshan-e-Iqbal Karachi, Pakistan. Journal of Biological and Environmental Science. 8, 64, 2016.

4. HASAN M., SHANG Y., AKHTER G., JIN W. Evaluation of groundwater suitability for drinking and irrigation purposes in Toba Tek Singh District, Pakistan. Irrig Drain. Syst. Eng. 6, 185, 2017.

5. EULENSTEIN F., TAUSCHKE M., SCHINDLER U., MÜLLER L., LANA M.A., SCHINDLER R., CREMER N. Agricultural Land Use Systems and Groundwater Quality: Impact Assessment Using Nutrient Balances for Evaluation, Monitoring and Conservation of Natural Resources. Agriculture and Agricultural Science Procedia. 11, 49, 2016.

6. BODRUD-DOZA M., ISLAM A.T., AHMED F., DAS S., SAHA N., RAHMAN M.S. Characterization of groundwater quality using water evaluation indices, multivariate statistics and geostatistics in central Bangladesh. Water Science. 30 (1), 19, 2016.

7. ZHAI Y., ZHAO X., TENG Y., LI X., ZHANG J., WU J., ZUO R. Groundwater nitrate pollution and human health risk assessment by using HHRA model in an agricultural area, NE China. Ecotoxicology and environmental safety. 137, 130, 2017.

8. QIU B., LU D., TANG Z., CHEN C., ZOU F. Automatic and adaptive paddy rice mapping using Landsat images: Case study in Songnen Plain in Northeast China. Science of the Total Environment. 598, 581, 2017.

9. WANG L., SEKI K., MIYAZAKI T., ISHIHAMA Y. The causes of soil alkalinization in the Songnen Plain of Northeast China. Paddy and Water Environment. 7 (3), 259, 2009.

10. ZHAO H.Q., ZHANG Z.H., CHEN Y. Lowering of groundwater level and its negative environment effects in the Songnen Plain. Journal of Arid Land Resources and Environment. 24 (1), 126, 2010.

11. LIU Q., CUI B., YANG Z. Dynamics of the soil water and solute in the sodic saline soil in the Songnen Plain, China. Environmental Earth Sciences. 59 (4), 837, 2009.

12. DONG Z., WANG Z., LIU D., SONG K., LI L., JIA M., DING Z. Mapping wetland areas using Landsat-derived NDVI and LSWI: A case study of West Songnen plain, Northeast China. Journal of the Indian Society of Remote Sensing. 42 (3), 569, 2014.

13. YUN J., YU Z., LI K., ZHANG H. Diversity, abundance and vertical distribution of methane-oxidizing bacteria (methanotrophs) in the sediments of the Xianghai wetland, Songnen Plain, northeast China. Journal of soils and sediments. 13 (1), 242, 2013.

14. TIAN H., LIANG X., GONG Y., KANG Z., JIN H. Health risk assessment of nitrate pollution in shallow groundwater: a case study in Changchun New District, China. La Houille Blanche. 5-6, 45, 2019.

15. TIAN H., LIANG X., GONG Y., QI L., LIU Q., KANG Z., JIN H. Health Risk Assessment of Nitrate Pollution in Shallow Groundwater: A Case Study in China. Pol. J. Environ. Stud. 29 (1), 827, 2020.

16. XIAOQING S., JIANMIN B., CHUNPENG Z., YU W., HANLI W., ZHUO J. Hydrochemistry Characteristics and Water Quality Assessment for Irrigation along the Second Songhua River in the South of the Songnen Plain, Northeast China. Polish Journal of Environmental Studies. 29 (1), 371, 2019.

17. BIAN J., NIE S., WANG R., WAN H., LIU C. Hydrochemical characteristics and quality assessment of groundwater for irrigation use in central and eastern Songnen Plain, Northeast China. Environmental monitoring and assessment. 190 (7), 382, 2018.

18. TIAN H., LIANG X., GONG Y., MA S., KANG Z., JIN H. Risk Assessment of Metals from Shallow Groundwater 
in Lianhuashan District, China. La Houille Blanche. DOI: 10.1051/lhb/2019063.

19. XIAO C., LIANG X., ZHANG F., FENG B., XIE S. Groundwater numerical simulation of multi-aquifers in Songnen plain. In Advances in Water Resources and Hydraulic Engineering (pp. 214-218). Springer, Berlin, Heidelberg. 2009.

20. ZHANG B., SONG X., ZHANG Y., HAN D., TANG C., YU Y., MA Y. Hydrochemical characteristics and water quality assessment of surface water and groundwater in Songnen plain, Northeast China. Water research. 46 (8), 2737, 2012.

21. WAGH V.M., MUKATE S.V., PANASKAR D.B., MULEY A.A., SAHU U.L. Study of groundwater hydrochemistry and drinking suitability through Water Quality Index (WQI) modelling in Kadava river basin, India. SN Applied Sciences. 1 (10), 1251, 2019.

22. ŞENER Ş., ŞENER E., DAVRAZ A. Evaluation of water quality using water quality index (WQI) method and GIS in Aksu River (SW-Turkey). Science of the Total Environment. 584, 131, 2017.

23. SOLEIMANI H., NASRI O., OJAGHI B., PASALARI H., HOSSEINI M., HASHEMZADEH B. FEIZABADI G.K. Data on drinking water quality using water quality index (WQI) and assessment of groundwater quality for irrigation purposes in Qorveh\&Dehgolan, Kurdistan, Iran. Data in brief. 20, 375, 2018.

24. ABBASNIA A., YOUSEFI N., MAHVI A.H., NABIZADEH R., RADFARD M., YOUSEFI M., ALIMOHAMMADI M. Evaluation of groundwater quality using water quality index and its suitability for assessing water for drinking and irrigation purposes: Case study of Sistan and Baluchistan province (Iran). Human and Ecological Risk Assessment: An International Journal. 25 (4), 988, 2019.

25. KUMAR S.K., BABU S.H., RAO P.E., SELVAKUMAR S., THIVYA C., MURALIDHARAN S., JEYABAL G. Evaluation of water quality and hydrogeochemistry of surface and groundwater, Tiruvallur District, Tamil Nadu, India. Applied Water Science. 7 (5), 2533, 2017.

26. KHAN R., JHARIYA D.C. Groundwater quality assessment for drinking purpose in Raipur City, Chhattisgarh using water quality index and geographic information system. Journal of the Geological Society of India. 90 (1), 69, 2017.

27. SOLANGI G.S., SIYAL A.A., BABAR M.M., SIYAL P. Evaluation of surface water quality using the water quality index (WQI) and the synthetic pollution index (SPI): a case study of Indus Delta region of Pakistan. Desalination and Water Treatment. 118, 39, 2018.

28. GAUTAM S.K., MAHARANA C., SHARMA D., SINGH A. K., TRIPATHI J.K., SINGH S.K. Evaluation of groundwater quality in the Chotanagpur plateau region of the Subarnarekha river basin, Jharkhand State, India. Sustainability of Water Quality and Ecology. 6, 57, 2015.

29. ROTIROTI M., BONOMI T., FUMAGALLI L. An integrated approach to asses origin and mobilization of $\mathrm{As}, \mathrm{Fe}$ and $\mathrm{Mn}$ in groundwater: the case study of Cremona (northern Italy). In EGU General Assembly Conference Abstracts 15, 2013.

30. VAN DIJK G., WOLTERS J., FRITZ C., DE MARS H., VAN DUINEN G.J., ETTWIG K.F., SMOLDERS A.J.P. Effects of groundwater nitrate and sulphate enrichment on groundwater-fed mires: a case study. Water, Air, \& Soil Pollution. 230 (6), 122, 2019.
31. RAVINDRA K., MOR S. Distribution and health risk assessment of arsenic and selected heavy metals in Groundwater of Chandigarh, India. Environmental pollution. 250, 820, 2019.

32. KARUNANIDHI D., ARAVINTHASAMY P., SUBRAMANI T., ROY, P.D., SRINIVASAMOORTHY K. Risk of fluoride-rich groundwater on human health: Remediation through managed aquifer recharge in a hard rock terrain, South India. Natural Resources Research. 1-27, 2019.

33. ALAMDAR R., KUMAR V., MOGHTADERI T., NAGHIBI S.J. Groundwater quality evaluation of Shiraz City, Iran using multivariate and geostatistical techniques. SN Applied Sciences. 1 (11), 1367, 2019.

34. ERICKSON M.L., YAGER R.M., KAUFFMAN L J., WILSON J.T. Drinking water quality in the glacial aquifer system, northern USA. Science of the Total Environment. 694, 133735, 2019.

35. ABBASNIA A., ALIMOHAMMADI M., MAHVI A. H., NABIZADEH R., YOUSEFI M., MOHAMMADI A.A. MIRZABEIGI M. Assessment of groundwater quality and evaluation of scaling and corrosiveness potential of drinking water samples in villages of Chabahr city, Sistan and Baluchistan province in Iran. Data in brief. 16, 182, 2018.

36. SAKRAM G., ADIMALLA N. Hydrogeochemical characterization and assessment of water suitability for drinking and irrigation in crystalline rocks of Mothkur region, Telangana State, South India. Applied Water Science. 8 (5), 143, 2018.

37. DAS M., NAYAK A.K., DAS B., VERMA O.P. Groundwater quality assessment and mapping using multivariate statistics and analytic hierarchy process in Bhubaneswar city, Odisha, India. International Journal of Water. 12 (3), 195, 2018.

38. ADIMALLA N., VENKATAYOGI S. Geochemical characterization and evaluation of groundwater suitability for domestic and agricultural utility in semi-arid region of Basara, Telangana State, South India. Applied water science, 8 (1), 44, 2018.

39. LI P., WU J. Drinking water quality and public health. Exposure and Health. 11 (2), 73, 2019.

40. SOLANGI G.S., SIYAL A.A., BABAR M.M., SIYAL P. Evaluation of drinking water quality using the water quality index (WQI), the synthetic pollution index (SPI) and geospatial tools in Thatta district, Pakistan. Desalination and Water Treatment. 160, 202, 2019.

41. ESLAMI F., SHOKOOHI R., MAZLOOMI S., DARVISH MOTEVALLI M., SALARI M. Evaluation of water quality index (WQI) of groundwater supplies in Kerman Province in 2015. Occupational and Environmental Health. 3 (1), 48, 2017.

42. ZINGDE M.D., SINGBAL S.Y.S., MORAES C.F., REDDY C.V.G. Arsenic, copper, zinc and manganese in the marine flora and fauna of coastal and estuarine waters around Goa. Indian J. Mar. Sci. 5, 212, 1976.

43. WHO. Guidelines for Drinking-Water Quality. World Health Organization, Geneva, Switzerland. 2008.

44. WOODING M., ROHWER E.R., NAUDÉ Y. Determination of endocrine disrupting chemicals and antiretroviral compounds in surface water: a disposable sorptive sampler with comprehensive gas chromatography-time-of-flight mass spectrometry and large volume injection with ultrahigh performance liquid chromatography-tandem mass spectrometry. Journal of Chromatography A. 1496, 122, 2017. 